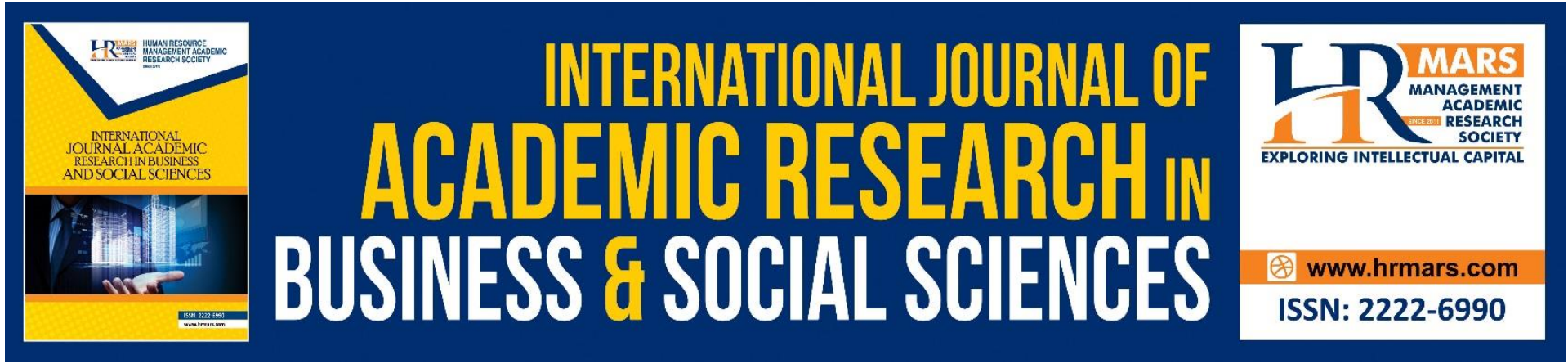

\title{
Developing A Strategic Halal Trade Performance Framework for Halal Food Import in Malaysia
}

Nor Bakhriah Sarbani, Harlina Suzana Jaafar

To Link this Article: http://dx.doi.org/10.6007/IJARBSS/v11-i9/10830

DOI:10.6007/IJARBSS/v11-i9/10830

Received: 12 July 2021, Revised: 01 August 2021, Accepted: 23 August 2021

Published Online: 08 September 2021

In-Text Citation: (Sarbani \& Jaafar, 2021)

To Cite this Article: Sarbani, N. B., \& Jaafar, H. S. (2021). Developing A Strategic Halal Trade Performance Framework for Halal Food Import in Malaysia. International Journal of Academic Research in Business and Social Sciences, 11(9), 152-161.

Copyright: (c) 2021 The Author(s)

Published by Human Resource Management Academic Research Society (www.hrmars.com)

This article is published under the Creative Commons Attribution (CC BY 4.0) license. Anyone may reproduce, distribute, translate and create derivative works of this article (for both commercial and non-commercial purposes), subject to full attribution to the original publication and authors. The full terms of this license may be seen at: http://creativecommons.org/licences/by/4.0/legalcode

Vol. 11, No. 9, 2021, Pg. 152 - 161

http://hrmars.com/index.php/pages/detail/IJARBSS

JOURNAL HOMEPAGE

Full Terms \& Conditions of access and use can be found at http://hrmars.com/index.php/pages/detail/publication-ethics 


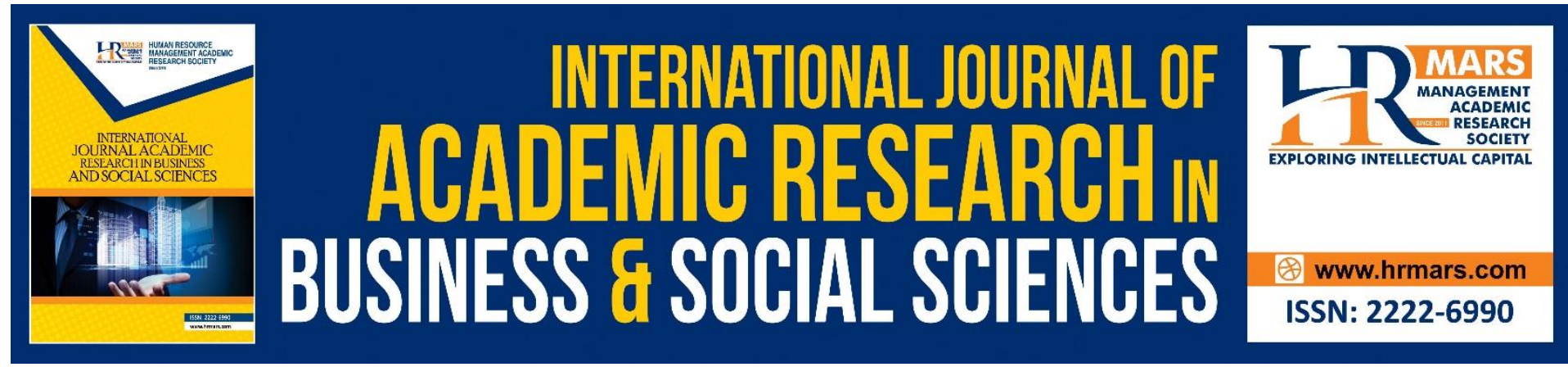

\title{
Developing A Strategic Halal Trade Performance Framework for Halal Food Import in Malaysia
}

\author{
Nor Bakhriah Sarbani ${ }^{1}$, Harlina Suzana Jaafar ${ }^{2}$ \\ ${ }^{1}$ Faculty of Management, PICOMS International University College, Kuala Lumpur, Malaysia, \\ ${ }^{2}$ Faculty of Business and Management, Universiti Teknologi Mara Selangor Branch, Selangor, \\ Malaysia \\ Email: harlinas@uitm.edu.my
}

\begin{abstract}
The considerably increasing demand for trading across border have involved massive border operation activities, thus dragged the supply chain into complicated activities. Trade facilitation becomes significant as it brings successful international measures to eliminate unnecessary time and cost burden associated with border administrative operations. Four main principles, namely simplification, harmonization, standardization, and transparency form the foundations of trade facilitation. These principles are translated into specific operational objectives namely speed, dependability, quality, cost and flexibility to measure the principal goals. Concurrently, the rising number of Muslim populations has called for more research in the trading of halal food. Asia Pacific, being the home of 240 million Muslims also contributes to its importance. Specifically, halal food is becoming highly concerned issues that is not limited to its production, but also in larger trading activities among countries. This study aims to develop a strategic halal trade performance framework for halal food import operations. Based on 15 semi structured interviews with stakeholders of food import border clearance, this study found that regulation, policy, knowledge, experience, visibility, commitment, attitude, mentality, and consistency were significant operational determinants to strategic operational performance across every facet of the border clearance activities in the context of Halal trade across the Malaysian border.
\end{abstract}

Keywords: Trade Facilitation, Cross-Border Import, Halal Logistics, Food Supply Chain, Operation Performance

\section{Introduction}

The considerably increasing demand for trading across border involves massive border operation activities, thus dragged the supply chain into complicated activities. Trade facilitation becomes significant as it brings successful international measures to eliminate unnecessary time and cost burden associated with border administrative operations based on four main principles, namely simplification, harmonization, standardization, and transparency. Generally, it implies the breadth of logistics activities that depend on the number of actors involved in the cross border supply chain process including the physical 
infrastructure services and the number of regulatory border control that are imposed on certain import trade (Shepherd \& Hamanaka, 2015).

Besides a huge effort on trade facilitation agenda, there is an increasing area of concern in the international trading involving halal trade logistics (e.g., Choudhury \& Biraima, 2002, Jaafar et al., 2011). This is because it is reported that the estimated global Muslim population will reach $26 \%$ of the world's population by 2030 (The Halal Journal, 2015). As the fastest growing religion, the demand for Halal food trade and other related services particularly logistics of the halal products also reflects an increasing trend (Lodhi, 2010). Thus, introduction of halal logistics as a sustenance to overall supply chain encourage the optimization of halal operations to safeguarding halal freight from harmful elements (Tieman \& Che Ghazali, 2013). This halal operational intention fulfills the right of the consumers to receive products that are free from contaminations. The emerging awareness on halal logistics put more challenges to trade facilitation efforts and so it was put into research attention from various perspective (Faradina et al., 2018). Previous studies in trade facilitation and halal logistics need further enlightenment for better research understanding. Consequently, this paper develops a strategic halal trade performance framework in the context of halal food import in Malaysia as manufacturing activities beyond the Malaysian border might subject to various and unstandardized halal compliance practices.

\section{A. Strategic Halal Trade Performance}

Generally, there are three main categories of operational actors involved in the cross-border trade environment and border formality process namely traders, intermediaries and government (Grainger, 2011). Within the import cross-border trading activities, the stakeholders particularly the importer and the exporter are the two key main actors, who initiate the business agreements between them, whilst the logistics process deals with the logistics service providers specifically on transportation of goods, costs and other related services (Jensen, Niels Bjørn-andersen, \& Vatrapu, 2014). In the early of 1980's, improvement strategy for effective cross-border import environment was influenced by innovative actions towards multitude factors including reduction of impediments from customs and trade policies within distribution channel (Anderson, 1985). Changes in trade and supply chain are driven by border public administration, which associate with various operational concerns related to logistics and transportation to offset sophisticated problem along the cross-border and international distributions (Hameri \& Hintsa, 2009). Hence, trade facilitation initiatives that relate to cross-border activities are affected by various factors including regional border integration and cross-border import infrastructure (Fujimura, 2004).

The key indicator for cross-border trade and transport facilitation relates to strategic performance objectives which generally support the intervention of logic by providing a referential basis for operational improvement that aligned with key strategic aspects of border-crossing activities and infrastructure. Slack et al, (2007) elaborate that the structured perspective of the framework facilitates understanding and allows deconstruction of complex issues concerning the facilitation of trade and transport across borders into specific operation performance elements such as speed, dependability, flexibility, quality and cost (Batista, 2012). Strategic operation paradigms are used widely in logistics and supply chain research especially for such decision-making support and performance strategy (Defee \& Stank, 2005; Kim, 2013; Skinner, Bryant, \& Richey, 2008; Trapczynski \& Wrona, 2013; Vivares-Vergara, Sarache-Castro, \& Naranjo-Valencia, 2016; Wong, Skipworth, Godsell, \& Achimugu, 2012). 


\section{B. Halal Logistics}

As the Muslims is becoming aware of the need to eat halal food as required by their religion, the demand for Muslim Halal dietary is growing along the rising of population and faith. The increasing needs is particularly crucial as Islam is recognized as the fastest growing faith with 2.14 billion believers around the world which recognized as the second biggest religion after the Christian faith (World Muslim Population, 2017). A study by the State of the Global Islamic Economy Report 2020/21 highlights that Muslims spent USD2.02 trillion across food, pharmaceutical, cosmetics, fashion, travel and media/creation sectors. It is forecasted that Muslims spending is reaching USD2.4 trillion by 2024 at a 5-year Cumulative Annual Growth Rate (CAGR) of $3.1 \%$. The halal food sector accounts the highest investment indicating $51.86 \%$. Thus, halal food is becoming highly concerned issues that is not limited to its production, but also in larger trading activities among countries. Consequently, it generates pertinent issues on the important effort of Halal food supply chain actors to protect the wholesomeness process of Halal food post-production to fulfill the need of the final Muslim consumers at the destination country. Thus, the role of Halal logistics that is bound with the standard principles according to Islamic teaching (Syariah) increases. Halal integrity in the logistics operation indicates the reliability of the beholder from farm to fork including warehousing, transportation and terminal operation (Tieman, Vorst, \& Ghazali, 2012). Halal logistics turn out to be an important requirement for trade of Halal food to safeguard the process that comply to the Islamic set of principles, standards and specifications in the logistics operation (Omar, Jaafar, \& Osman, 2010). Even though Halal products appear to be similar to other types of food, but the way it is prepared, handled and processed from the origin right up to the retailer's shop should be free from contaminations in accordance with Islamic requirements (Kalantari Shahijan, Rezaei, Preece, \& Ismail, 2014). In the context of food import, the destination country border procedures are crucial as it is a compulsory formality requirement before the food is released to the market. At the border environment, trade facilitation portrayed as the utmost important support during import clearance as a protection from formalities causing trade hurdles.

Thus, based on the justifications, this paper intends to develop a Strategic Halal Trade Performance framework in the context of halal food import cross border in the sea freight operations. The model explains the crucial indicators that would lead to a successful trade of imported halal food.

\section{Research Methodology}

Based on a qualitative research approach, 15 face-to-face in-depth interviews were conducted with selected sea freight cross border stakeholders, who involve in food import clearance operation. The Malaysian international cross-border import communities, namely The Royal Malaysian Customs; Malaysia Quarantine and Inspection Services (MAQIS); Food Quality and Safety Division, Health Department; warehouse operator (free zone area), terminal operator and customs brokerage agent participated as respondents (refer to Table 1). A set of six open-ended control questions was developed and used based on the existing trade facilitation practice for food import clearance. 
Table 1: List of participants in the case study

\begin{tabular}{|l|c|}
\hline List of Agencies Involved in the Interviews & $\begin{array}{c}\text { Number Of } \\
\text { Participants }\end{array}$ \\
\hline Royal Malaysian Customs (RMC) & 5 \\
\hline $\begin{array}{l}\text { Malaysia Quarantine and Inspection Services } \\
\text { (MAQIS) }\end{array}$ & 3 \\
\hline Department of Health & 3 \\
\hline Terminal Operators & 1 \\
\hline Warehouse operator & 1 \\
\hline $\begin{array}{l}\text { Customs Brokerage agency/logistics } \\
\text { operators }\end{array}$ & 2 \\
\hline TOTAL & 15 \\
\hline
\end{tabular}

The interviews began with initial questions of introductory in nature, aiming to assess the overall perceptions of the interviewees on the evolution of Halal trade cross border import operation as well as identifying the indicators leading to successful halal trade import performance.

\section{Results and Discussion}

The main results of the study were discussed in the context of strategic and operational sea freight cross-border trade facilitation of Halal food import. Based on the case study, three pertinent operational factors were found to strongly influence the effective import clearance activity operations. They are physical handling, data and documentation as well as relevant strategic operational factors. The explanations on the process are as follows:

1) Physical Handling for Halal food import

During cross-border import activities, three important stages involving physical cargo handling were identified, namely the handling at the terminal, authority examinations and storage at the agents' premises. The three physical handling stages are crucial on food import especially Halal food consignment before it is released to the local destination.

- $\quad$ Food Handling at the terminal

Food handling at the terminal is a crucial activity for all types of cross-border imports particularly the sea freight operation. This is because the seaport terminal plays a vital role in cargo handling which commonly involve both human intervention and various handling equipment to move physical consignment from the carrier to the temporary storage located at the dedicated free zone space while waiting for shipment clearance. Several important activities associated to the terminal handling operations depend on border environment and cargo unitization. During the transit of cargo at the seaport, Halal food consignment may expose to handling risk that may lead to food contamination especially for Less Container Load (LCL) type of shipment. In this study, it was found that for food consignments, the shippers' declaration in electronic manifest, which appears in the port system has no indication that the food consignment is halal. As a result, the terminal operator faces difficulties to locate the containers that are loaded with halal cargo. In this situation, the chances of cross-contamination of halal and non-halal cargo or hazardous cargo might occur.

- Inspection by Authority

Another crucial stage for Halal food consignment at the cross-border is the authority examinations. Two examinations conducted by the related authorities are physical inspections and sampling process for lab testing. The results showed that the same standard 
operating procedures that applies to the clearance of halal food consignment in the import operation may lead to halal food contamination. The tariff code selection in the electronic declaration system plays an important role in determining the way that the goods will be examined by the enforcement agencies. Under the food tariff code category, most consignment need to be inspected by the Health Department for Food Safety Control for Human Consumption and the Malaysia Quarantine and Inspection Service (MAQIS) who is responsible for food item control to ensure safety of the local animal and domestic plantations. Both authorities conduct basic inspection procedures within their jurisdiction that involve physical handling activities. Based on judgement of the officer in duty, the authorized agency may grant clearance approval to the shipper, thus ignoring the requirements of the halal food products. On the other hand, the authorized agency may also request the officer on duty to conduct further investigation in any event of peculiar or suspicious condition of the physical cargo. Consequently, the Royal Malaysian Customs (RMC) examines and assesses the cargo value and import volume before the cargo are released to the importers or their forwarding agents. In the absence of Halal inspection guidelines of physical cargo at the border, the physical halal examination was not conducted. Thus, crosscontamination might occur at the inspection bay, tools or human intervention with the physical halal consignment.

\section{- $\quad$ Storage in free zone warehouse}

Some import consignments need to be stored in the storage facilities in the free zone area. This is part of the strategy to reduce the clearance cost, especially for dutiable cargo. Free zone storage service provides import facilities to clear their import consignment through partial clearance. The data indicated that the halal food was stored using the current warehouse operation practices. It is common that warehouse in the free zone, which operates under conventional environment does not address the halal issues as indicated in the Halal standard guidelines. The necessary requirements were not followed including the Halal food consignment. Therefore, the halal implementation and practice as indicated in the Malaysia Standard Halal Supply Chain Management System - Part 2: Warehousing - General Requirements, MS2400-2:2019 was not complied. Thus, most food consignments are handled by non-halal certified free zone warehouse, who consolidates halal and haram products or halal and hazardous products during storage and transportation for final delivery. Equipment and tools for Halal and non-Halal are not segregated either in the dry warehouse or cold-room storage. This implementation exposes the food consignments to potential cross contamination.

\section{2) Data and Documentation for Halal import clearance}

In the second operational activities, the findings were associated to the data and documentation in Halal import clearance. The identity of every import consignment is determined by information declared in the electronic platform and supporting documents presented to the related authorities as part of the assessment process. Thus, three factors were found to influence the facilitation objectives for Halal food import.

- $\quad$ Electronic Data Declaration

Import declaration involves declaration from the shipping agents through the electronic manifest (e-Manifest) to indicate a general description of a shipment. Electronic manifest is linked to the Customs Information System (SMK), which is a special database system for crossborder activities hosted by Royal Malaysian Customs that is shared with other authorities. The information from e- manifest is used by port authorities and regulators as a preliminary signal to prepare their operational plan according to their designated procedures. For 
example, food in the manifest is declared as meat without detail descriptions. The subjective description will automatically trigger both the Health Department and MAQIS as relevant food authorities for physical inspection. Consignment will be checked and remarked by both agencies in a specific system for import declaration.

Meanwhile, importers' agents are accountable to declare import shipment in another system known as electronic declaration system (e-Declare) which also linked to the SMK. The state and condition of every product's descriptions and shipping information are revealed in the declaration including the right tariff to represent product classification which determines the values of duty and taxes as well as regulatory process related to the specific consignment. The tariff code selection system will respond automatically to relevant authority's approval the moment electronic declaration is sent for assessment. The information will then be crossed assessed with inspection findings and all required documents as per import requirements. Clearance progress will then appear in the import system screen which can be accessed by all authorities as well as registered public users.

Besides the three main reference system, there is also an additional import risk assessment tool used by Health Department known as Food Safety Information System of Malaysia (FOSIM) for the purpose of all food safety control and requirement subject to the International Food Act and Malaysian Food Regulations. However, the import risk assessment does not include Halal consignment criteria.

- $\quad$ Physical Document Assessments

Presentation of related trade and shipping documents is a compulsory requirement for crossborder import clearance. Specifically, for food import shipment, a copy of custom declaration is submitted with of trade documents (invoice, packing list, import permit, certificate of origin, etc.) and shipping certificate as evidence known as Bill of Lading (BOL). Two additional documents entwined with food import is health certificate as well as Halal certificate for Halal meat and poultry. Physical documents undergo detail assessment process by respective authorities' officers. Based on the current import requirement, Halal certificate is required only for meat and poultry import, but not for other category of food import. These findings show that majority of food import was not filtered and examined accordingly with Halal control procedures during its arrival through sea freight modes.

3) Elements of strategic operational performance for Halal food import

In addition to Section 1 and 2, the findings have highlighted the importance of specific operational discoveries for trade facilitation of Halal food import. These operational elements were gathered from the current trade facilitation practice and from operational concerned related to Halal food import clearance. All presented elements were found from central activities related to Halal food import which have been discussed in the previous section of this paper involving certain activities during import operation. Thus, the nine elements identified from related issues in physical handling and documentations process for Halal food import are summarized in Table 2: 
Table 2: Summary of Findings indicating Trade facilitation factors for Halal food import.

\begin{tabular}{|c|c|c|}
\hline Elements & Trade Facilitation & Halal trade import clearance \\
\hline Regulation & $\begin{array}{l}\text { - } \begin{array}{l}\text { Existing border procedures are } \\
\text { based on established } \\
\text { International and Local Acts. }\end{array} \\
\end{array}$ & $\begin{array}{l}\text { - Lack of clear Halal mechanism to } \\
\text { determine and justify Halal control for } \\
\text { border authority. }\end{array}$ \\
\hline Policy & $\begin{array}{l}\text { - Enforcement agency dilemma } \\
\text { on agents' tendency to } \\
\text { complaint to the higher } \\
\text { authority. }\end{array}$ & $\begin{array}{l}\text { - Foreign certifying bodies are subjected } \\
\text { to the Department if Islamic } \\
\text { Development (JAKIM) approval though } \\
\text { join approval with veterinary } \\
\text { department. }\end{array}$ \\
\hline Knowledge & $\begin{array}{l}\text { - Import process assessment } \\
\text { varies depending on the officers' } \\
\text { knowledge on regulation. }\end{array}$ & $\begin{array}{l}\text { - Decision making constraint related to } \\
\text { Halal product due to lack of officer } \\
\text { knowledge on Halal food products' } \\
\text { assessment. }\end{array}$ \\
\hline Experience & $\begin{array}{l}\text { - Verification of information and } \\
\text { documentations are depending } \\
\text { on officer's experience. }\end{array}$ & $\begin{array}{l}\text { - Ability or experience of Other } \\
\text { Government Agencies' (OGA) officer } \\
\text { detecting the authenticity of the Halal } \\
\text { certificate. }\end{array}$ \\
\hline Visibility & $\begin{array}{l}\text { - SMK is linked with OGA to } \\
\text { ensure clearance process is } \\
\text { transparent to other } \\
\text { stakeholders. }\end{array}$ & $\begin{array}{l}\text { - Lack of specific tariff code for halal } \\
\text { goods import immediate identification. }\end{array}$ \\
\hline Commitment & $\begin{array}{l}\text { - Low compliance level of the } \\
\text { agents is still a challenge to } \\
\text { assessment officer. }\end{array}$ & $\begin{array}{l}\text { - Responsibility to produce genuine Halal } \\
\text { label for foreign origin food (other than } \\
\text { meat and poultry). }\end{array}$ \\
\hline Mentality & $\begin{array}{l}\text { - } \begin{array}{l}\text { Agents attempt to commit fraud } \\
\text { documents and cheat } \\
\text { information. }\end{array} \\
\end{array}$ & $\begin{array}{l}\text { - Agents' negative mentality towards } \\
\text { Halal operation. }\end{array}$ \\
\hline Attitude & $\begin{array}{l}\text { - Clearance agents' tactics to get } \\
\text { fast approval from their favorite } \\
\text { officer especially for tricky } \\
\text { import consignment }\end{array}$ & $\begin{array}{l}\text { - Other OGAs are aware on the Halal } \\
\text { issue but not considering any action in } \\
\text { their related border responsibility. }\end{array}$ \\
\hline Consistency & $\begin{array}{l}\text { - Random physical examination is } \\
\text { rarely conducted due to limited } \\
\text { number of officers. }\end{array}$ & $\begin{array}{l}\text { - Halal import certificate requirements } \\
\text { for Halal food import other than } \\
\text { poultry and meat products. }\end{array}$ \\
\hline
\end{tabular}

The above elements play important role in every clearance stage because they influence the trade facilitation performance especially for cross-border import clearance for Halal food products into Malaysia. The elements originated from detail analysis of cross border import clearance process in the selected sea freight cross border operation environment.

\section{Conclusion}

This paper provides insights on the cross-border import activities especially on the current trade facilitation implementation and Halal food import practices in sea freight context involving transfer of physical cargo as well as information and documentation assessment for authorized food import. Accordingly, strategic halal trade performance indicators in the Halal 
cross border activities were proposed. The results exhibited that there were three crucial activities need to be monitored to ensure effective performance of imported halal consignment cross border trade in the context of sea freight cross border clearance process particularly the terminal operation, authorities' inspections, and agents' storage. On the other hand, the electronic information and physical documentation verification were very important during border import activity involving desk assessment for import approval process. This research identified the needs to embed the newly discovered additional strategic halal trade performance indicators in the context of Halal food consignment crossborder clearance performance. Consequently, the findings in this study enhanced the existing indicators highlighted by the previous studies leading to the novelty of this research. This is crucial to enhance the performance objective measurement to ensure accuracy in its implementation. It is important to note that the results from this study was derived from the perspective of border clearance stakeholders in the context of sea freight cross border community perspective. Similar studies on cross-border environment involving rail/road land import cross-border as well as airfreight import procedures may also be conducted using the same qualitative methodological approach as a consideration of future research.

\section{Acknowledgement}

We express our warm and sincere appreciation to the Ministry of Higher Education of Malaysia for the provision of the research grant from the Fundamental Research Grant Scheme (FRGS/1/2017SS01/UiTM/02/8) to successfully conduct the research. We also acknowledge the support given by the Malaysia Institute of Transport (MITRANS), Universiti Teknologi MARA (UiTM), Malaysia in completing the research. Special appreciation also goes to the interview participants and the research team members.

\section{References}

Anderson, D. L. (1985). International Logistics Strategies for the 1980s. International Journal of Physical Distribution \& Materials Management, 15(4), 5-19.

Batista, L. (2009). Key Operations Performance Factors on Trade and Transport Facilitation. In Logistics Research Network Conference. Cardiff, UK: The Open University. Retrieved from http://oro.open.ac.uk/25233/1/LRN2009_Paper_LucianoBatista.pdf

Batista, L. (2012). Translating Trade and Transport Facilitation into Strategic Operations Performance Objectives. Supply Chain Management: An International Journal, 17(2), 124-137. https://doi.org/10.1108/13598541211212870

Choudhury, M. A., \& Biraima, M. A. (2002) Normative Issues Relating to Trade and Development in the OIC Membership in the Light of Islamic Political Economy, Humanomics 18(3), 42-64.

Defee, C. C., \& Stank, T. P. (2005). Applying the strategy-structure-performance paradigm to the supply chain environment. The International Journal of Logistics Management, 16(1), 28-50. https://doi.org/10.1108/09574090510617349

Faradina, A., Hussein, M. Z., Husny, Z. J., Yazid, M., Mazlan, Z., Fauziah, A. R., Zani, M., and Adnan, N. (2018) Halal Logistics: Halal Integrity and Legal Enforcement Challenges, International Journal of Supply Chain Management, 7(4),6.

Fujimura, M. (2004). Cross-border Transport Infrastructure, Regional Integration and Development. ADB Institute Discussion Papers.

Grainger, A. (2011). Trade Facilitation: A Conceptual Review. Journal of World Trade, 45(1), 39-62. 
Hameri, A.-P., \& Hintsa, J. (2009). Assessing the Drivers of Change for Cross-border Supply Chains. International Journal of Physical Distribution \& Logistics Management, 39(9), 741-761. https://doi.org/http://dx.doi.org/10.1108/09600030911008184

Jaafar, H. S., Endut, I. R., Faisol, N., Omar, E. N. (2011) Innovation in Logistics Services: Halal Logistics, Proceedings of the $16^{\text {th }}$ International Symposium on Logistics (ISL): 844-851, Berlin, Germany, 10-13 July ISBN: 978-085358-279-3.

Jensen, T., Bjørn-andersen, N., \& Vatrapu, R. (2014). Avocados Crossing Borders : The Missing Common Information Infrastructure for International Trade. In CABS2014 (pp. 15-24). Kyoto, Japan: ACM.org. https://doi.org/10.1145/2631488.2631500

Shahijan, K. M., Rezaei, S., Preece, C. N., \& Ismail, W. K. W. (2014). Examining Retailers' Behaviour in Managing Critical Points in Halal Meat Handling: A PLS Analysis. Journal of Islamic Marketing, 5(3), 446-472. https://doi.org/10.1108/JIMA-10-2013-0070

Kim, D. (2013). Relationship between supply chain integration and performance. Journal of Operational Management Research, 6, 74-90. https://doi.org/10.1007/s12063-0130079-0

Lothi, A. H. (2010), Understanding Halal Food Supply Chain, HFRC UK Limited

Omar, E. N., Jaafar, H. S., \& Osman, M. R. (2010). Halal Supply Chain: A Preliminary Study of Poultry Industry. Advances in Business Research International Journal, 98-109.

Shepherd, B., \& Hamanaka, S. (2015). Overcoming Trade Logistics Challenges: Asia-Pacific Experiences. Asia Pacific Journal of Marketing and Logistics, 27(3), 444-466. https://doi.org/10.1108/APJML-09-2014-0133

Skinner, L. R., Bryant, P. T., \& Richey, R. G. (2008). Examining the Impact of Reverse Logistics Disposition Strategies. International Journal of Physical Distribution \& Logistics Management, 38(7), 518-539. https://doi.org/10.1108/09600030810900932

Trapczynski, P., \& Wrona, T. (2013). From Going International to being International Strategies for International Competitiveness. Poznań University of Economics Review, 13(1).

Vivares-Vergara, J. A., Sarache-Castro, W. A., \& Naranjo-Valencia, J. C. (2016). Impact of Human Resource Management on Performance in Competitive Priorities. International Journal of Operations \& Production Managemen, 36(2), 114-134.

Wong, C., Skipworth, H., Godsell, J., \& Achimugu, N. (2012). Towards a Theory of Supply Chain Alignment Enablers: A Systematic Literature Review. Supply Chain Management: An International Journal, 17(4), 419-437. https://doi.org/10.1108/13598541211246567. 